\title{
Mitigation and Adaptation of Community using AHP in Earthquake Disaster-Prone Areas in Pagar Alam City - Indonesia
}

\author{
Aulia Asman, Eri Barlian, Dedi Hermon, Indang Dewata, Iswandi Umar
}

\begin{abstract}
This study aims to formulate the mitigation and adaptation of community in Pagar Alam City using Analytical Hierarchy Process (AHP) techniques. The analysis result shows determining mitigation, physical, educational, and socio-economic use is used as a criterion with 8 alternative policies, i.e a) Participatory mapping to determine the hazards and risks of disasters; b) Increasing public awareness of volcanic earthquake disasters and their mitigation; c) Increasing coordination of related agencies; d) reviving wisdom local; e) building communication networks in the community; $f$ ) developing sister village programs; g) managing and structuring disaster-prone areas to reduce the threat of disasters, and h) programs to improve community preparedness in disaster management. Furthermore, adaptation has 3 criteria, physical, social, cultural and economic. Alternative as well as a priority in the implementation of successive volcanic earthquake adaptation, i.e a) changes in house construction to be earthquake resistant as a form of adaptation to earthquake disasters; b) Making youth as a driving factor in disaster risk reduction and increasing regional resilience; c) Application of local wisdom in daily life days; d) Building a culture of safety and resilience by using knowledge of innovation and education; e) evacuation routes are accompanied by signs and preparing basic needs; f) doing alternative work to meet financial needs; g) locating new homes closer to the main road, and h) separation of protected areas and clear cultivation areas.
\end{abstract}

Keywords: disaster-prone, earthquake, mitigation, pagar alam.

\section{INTRODUCTION}

Indonesia is an archipelago located at the confluence of four tectonic plates namely the Asian Continent, the Australian Continent, the Indian Ocean Plate and the Pacific Ocean. In the southern and eastern parts of Indonesia, there is

Revised Manuscript Received on May 15, 2020.

* Correspondence Author

Aulia Asman*, his/her Program of Diploma III Nursing and doctoral program of environmental science, Universitas Negeri Padang, Padang, Indonesia. Email: aulia.asman@gmail.com

Eri Barlian, Department of doctoral program of environmental science, Universitas Negeri Padang, Padang, Indonesia. Email: eribarlian@unp.ac.id

Dedi Hermon, Department of geography and doctoral program of environmental science, Universitas Negeri Padang, Padang, Indonesia. Email: dihermon006@gmail.com

Indang Dewata, Department of doctoral program of environmental science, Universitas Negeri Padang, Padang, Indonesia. Email: indangdewata@fmipa.unp.ac.id

Iswandi Umar, Department of geography and doctoral program of environmental science, Universitas Negeri Padang, Padang, Indonesia. Email: iswandi_u@yahoo.com

(c) The Authors. Published by Blue Eyes Intelligence Engineering and Sciences Publication (BEIESP). This is an open access article under the CC BY-NC-ND license (http://creativecommons.org/licenses/by-nc-nd/4.0/) a belt of volcanic (volcanic arc) that extends from the island of Sumatra, Java to Nusa Tenggara and Sulawesi, the sides in the form of old volcanic mountains and lowlands partly dominated by swamp-marsh [1]. Based on that geographic issues, Indonesia has the potential to become a country prone to natural disasters, especially volcanic eruptions and earthquakes volcanic. The Natural disaster can cause great suffering for the people of Indonesia, such as the loss of life, loss of property, the occurrence of environmental damage and destruction of development results that already achieved so far [2]. Mitigation is an effort to reduce the impact of disasters on the health and safety of people's lives [3], which can be done with physical development or increasing awareness and ability of the community to deal with the threat of disasters, while adaptation is an effort that needs to be done by the community to reduce the risk of disasters even living with disasters. Mitigation and adaptation must do because it does not make the volcanic disaster-stricken people living in areas of a volcanic deterrent. Displaced when a disaster occurs, then return to its original place in the aftermath of a disaster, is a phenomenon that is often found in various areas that have volcanoes. Damage, destruction and death due to volcanic earthquakes and volcanic eruptions are considered to be a consequence.Sumatra island became one of the islands that have an active volcano, one in South Sumatra Province, i.e Dempo Volcano. Dempo Volcano located in Pagar Alam City has vast and wide crater, which affects the increase in volcanic activity changing by the time. The crater of Dempo Volcano shaped lava lake of 3,000 $\mathrm{m}^{2}$, which is formed by a massive eruption in 1838. The eruption of Dempo Volcano recorded since 1818, where the last eruption occurred on January 1, 2009, and on April 5, 2019, the status of Dempo volcano in some time become Level II (alert) [4]. The area included in the Dempo Volcano danger area consists of Lahat Regency, Empat Lawang and Pagar Alam City with a total area of 36,850 Ha or around $0.40 \%$ of the total area of South Sumatra Province. So when an earthquake or volcanic earthquake is caused by Dempo Volcano, the four districts will feel a considerable impact. Because of the magnitude of risk at any time of volcanic earthquakes, the necessary mitigation and adaptation measures that need to be people around the area of Dempo Volcano. This study aims to formulate the mitigation and adaptation of community in earthquake disaster-prone areas in Pagar Alam City.

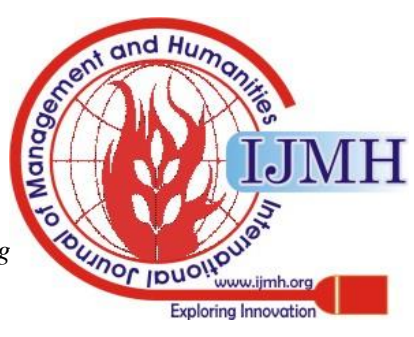




\section{METHODOLOGY}

This research is included in the category of qualitative research by collecting data through in-depth interviews (in-depth interview) and Focus Group Discussion (FGD).

The FGD is carried out with the Regional Disaster Management Agency (BPBD), the heads of the related agency, the head district, the Village Head, the community and members who concerned about the disaster. The results obtained were processed using Expert Choice 11, which was then analyzed using the AHP technique. Policy alternatives generated in the FGD were analyzed using the AHP method [5] to obtain policy priorities. Work Principle of AHP consists the preparation of hierarchy (decomposition), assessment criteria and alternatives (comparative judgment), priority setting (synthesis of priority), as well as logical consistency (local consistency) [6, 7]. In the evaluation of criteria and alternatives, the pairwise comparison is used using a scale of 1 to 9 as shown in Table 1 below.

Table-I: Banding Scale in Pairs

\begin{tabular}{|c|l|}
\hline Value & \multicolumn{1}{|c|}{ Description } \\
\hline 1 & Equally important \\
3 & Somewhat more important one over other \\
5 & Quite important \\
7 & Very important \\
9 & Extreme smoothness \\
$2,4,6,8$ & The Middle value between two adjacent decisions \\
\hline
\end{tabular}

Source [5-7]

\section{RESULT}

When there is a disaster that people can experience a loss directly or indirectly [8]. Direct loss such as damage, injury, repair or renovation costs for public and private structures, relocation/temporary housing costs, loss of business, emergency response costs, to the cost of cleaning up from the effects of disasters; whereas indirect losses have long-term effects on society such as loss of income, loss of input and business output, income reduction, loss of knowledge (education), psychiatric illness, to death [9].

Thus, mitigation and adaptation is a must, because volcanic disasters do not deter people from living in volcanic areas. Displaced when a disaster occurs, then return to its original place in the aftermath of a disaster, is a phenomenon that is often found in various areas that have volcanoes. This shows that there is a special attraction for the community in the volcanic area and there is a push to return to its original place after evacuation [10-12]. This why on the slopes of active volcanoes in Indonesia populated by human settlements [13]. The trend is supposed to make people ready and alert in case of an earthquake or volcanic eruption fire. Lack of knowledge that people have to start disaster preparedness movement is institutionalized into a major cause of casualties [14]. Therefore, to prepare policies related to mitigation, 3 criteria are used which consist of physical, educational, and social-economic. The following are alternative policies in mitigation that can be applied in the event of a volcanic earthquake in Dempo Volcano:

1. Program for increasing community preparedness in disaster management

2. Increasing public awareness about the volcanic earthquake and its mitigation [15]

3. Revive local wisdom [16-19]

4. Participatory mapping to find out the hazards and risks of disasters

5. Building communication networks in the community

6. Develop a sister village program

7. Arrangement and structuring of disaster-prone areas to reduce disaster threats

8. Improve coordination of related agencies.

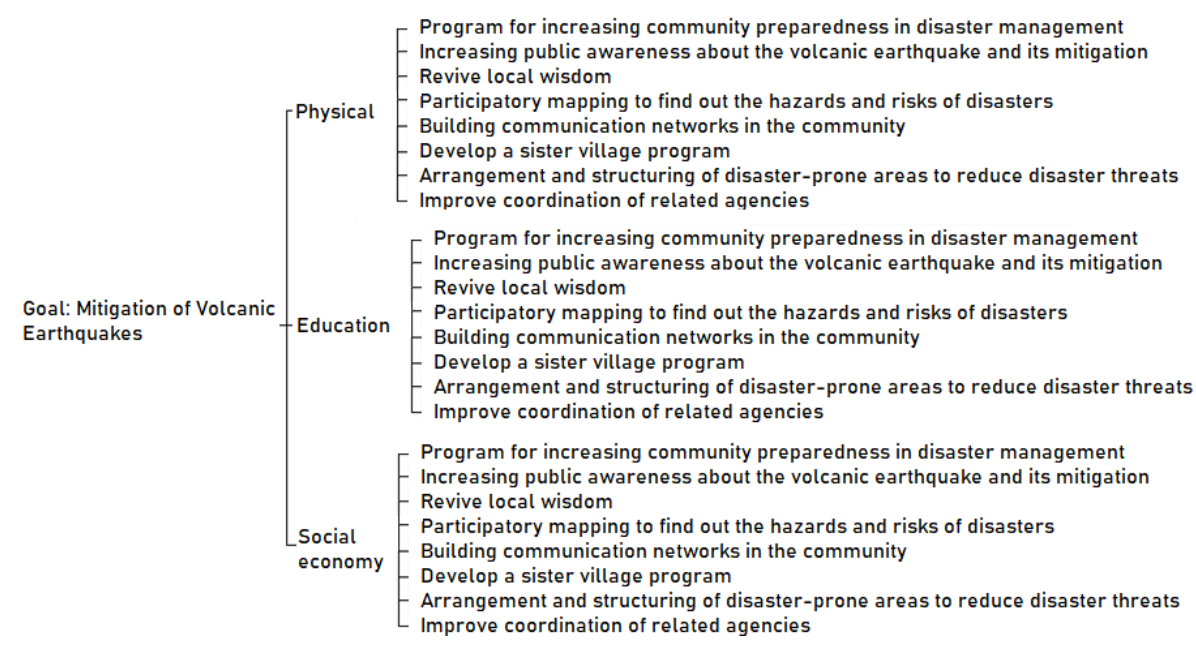

Fig 1. Hierarchy of Volcanic Earthquake Disaster Mitigation Policies

The criteria and alternative of volcanic earthquake disaster mitigation policies produced from FGDs are used as the basis for preparing the hierarchical structure of the volcanic earthquake disaster mitigation policies on Dempo Volcano. The results of the AHP show a combined assessment of policy criteria and alternatives. In Fig. 1 it appears that the goals achieved to solve the problem are placed at the highest level in the hierarchy. The next level is the elaboration of these objectives which can be completed by setting key indicators or criteria. Then, from each criterion, an alternative policy is produced which is a detailed description of the achievement of these objectives.

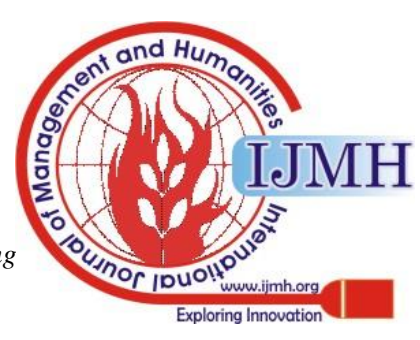


Policy criteria and alternatives assessed by experts at the time of the FGD on the hierarchy have a good level of consistency. The consistency value is indicated by the value of the consistency ratio (CR) smaller than 0.1. Fig. 2 shows that of the 3 criteria, physical criteria have pairwise assessment criteria showing a value of 0.04 . This assessment produces a weighting value on each element while describing the priority of each element [22-24]. Thus, experts in providing an assessment of the criteria, are consistent and can be ascertained that the order of priorities generated according to the needs and logical.

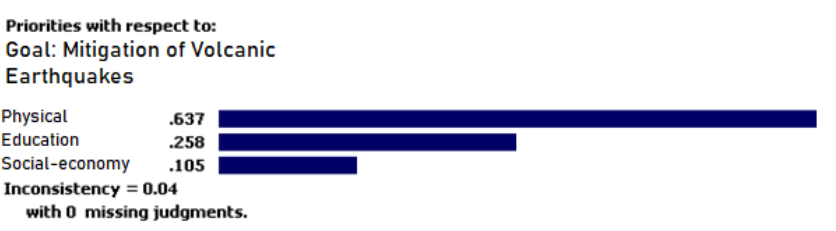

Fig 2. Consistency Value of Volcanic Earthquake Mitigation Criteria

In mitigation, there is a decision to do what and where related to health problems, safety and welfare of the community that has been determined and implemented as a risk reduction program, both for lives and property and its impact [25]. The results of paired assessments between criteria and between policy alternatives carried out by experts, produce policy priorities. That is, of the 8 alternative volcanic earthquake mitigation policies on Dempo Volcano, the priority to be implemented is the alternative that has the highest weight. In this study, 3 priorities of volcanic earthquake disaster mitigation policies were chosen at Dempo Volcano, i.e participatory mapping to find out the hazards and risks of disaster (37.8\%), increase public awareness about volcanic earthquake disasters and their mitigation (22.1\%), and improve coordination of related agencies (12.8\%) (Fig. 3). These 3 priorities can be realized with the following strategies:

1. Participatory mapping to find out the hazards and risks of disasters

2. Increasing public awareness about the volcanic earthquake and its mitigation

3. Improving the coordination of relevant agencies

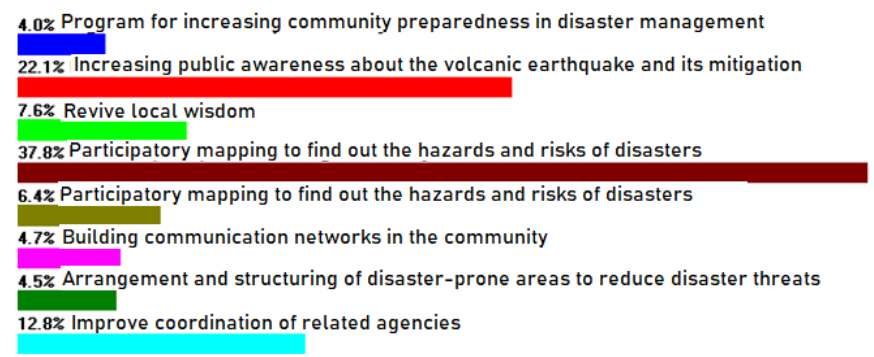

\section{Fig 3. Policy Priorities for Volcanic Earthquake Mitigation}

Furthermore, the adaptation of volcanic earthquake disaster is the ability of the community to adapt to the conditions of the environment that is prone to disasters. This adaptation was carried out directly by the community, where based on the results of interviews and FGD 3 criteria were obtained namely physical, educational, and socio-economic. The 3 criteria, have alternative policies as follows:

1. The evacuation route is accompanied by signs and has prepared basic needs

2. Doing alternative work to meet financial needs

3. Build a culture of safety and resilience by using knowledge of innovation and education

4. Changes in house construction to be earthquake resistant as a form of adaptation to earthquake disasters.

5. The location of the new house which is closer to the main road

6. Making youth as a driving force in reducing disaster risk and increasing regional resilience

7. Application of local wisdom in daily life

8. Clear separation of protected areas and cultivation areas

The resulting hierarchy related to the adaptation of volcanic earthquake disaster as a goal or goal of completion can be seen in Fig. 4. Criteria that have the highest weight or most influential in the adaptation of volcanic earthquake disaster are physical (physical condition of the environment or physical development). From the assessment of paired criteria, a consistency ratio value of 0.04 or smaller than 0.1 is obtained. That is, the judgments given are consistent and the order of priorities generated is as needed.

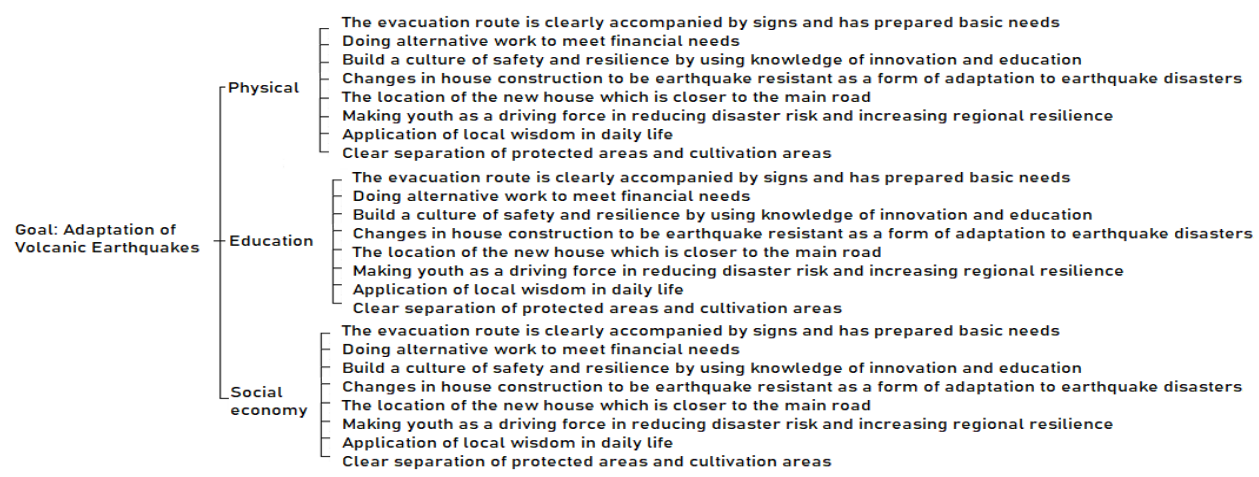

Fig 4. Hierarchy of Volcanic Earthquake Disaster Adaptation Policies

Published By:

Blue Eyes Intelligence Engineering \& Sciences Publication

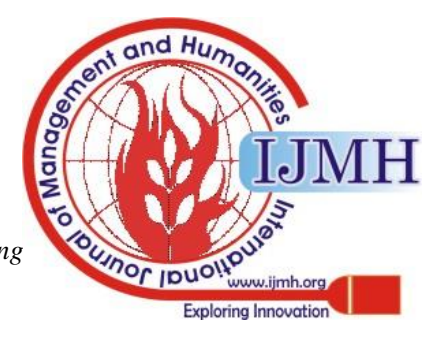




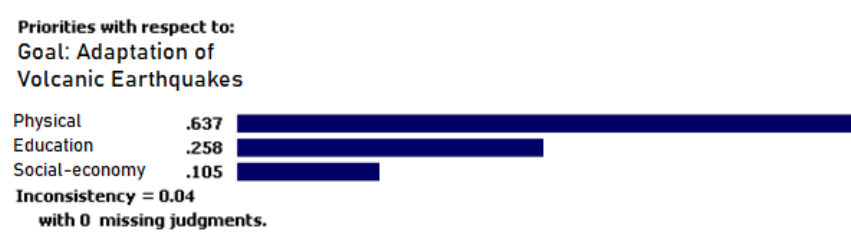

Fig 5. Consistency Value of Volcanic Earthquake Disaster Adaptation Criteria

The results of the 3 policy priorities obtained for adaptation to successive volcanic earthquake disasters are changes in the construction of houses to be earthquake resistant (38.3\%), making youths as movers (22.2\%), and applying local wisdom (13.6\%) (Fig. 6). These 3 priorities can be realized with the strategy as follows:

1. Change in house construction to be earthquake resistant

2. Making youth as a driving factor

3. The application of local wisdom

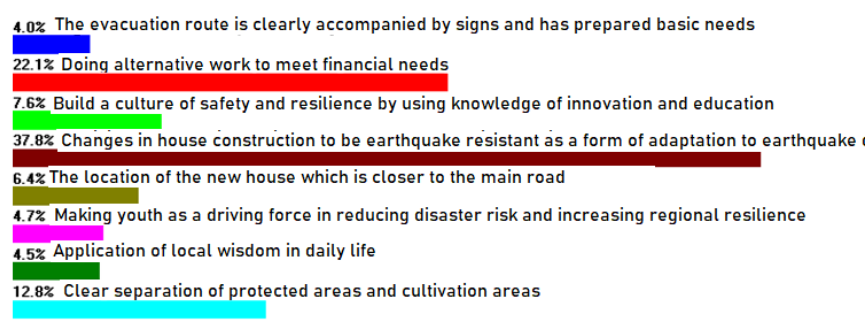

\section{Fig 6. Priority Policy on Adaptation of Volcanic Earthquake Disasters}

From the results of the adaptation above, it is known that from the past people in Pagar Alam City, located at the foot of Dempo Volcano, have known local wisdom towards the volcanic earthquake. This can be seen from the Basemah house as a traditional house that already uses the concept of earthquake-resistant houses. Besides, people are also used to being in harmony with nature in their daily lives. However, the people in Pagar Alam City are very adaptive to the development of science and technology and even to collaborate with the government and the wider community.

Priority results on the mitigation and adaptation of volcanic earthquake disasters in Pagar Alam City resulting from FGDs with experts in their fields are expected to be a reference for the government in suppressing the number of disaster victims. Mitigation and adaptation can take the form of efforts through the construction of special facilities and the application of certain technologies [26]. For people who are in disaster-prone areas, there are 5 types of vulnerability faced in social contexts, namely:

1. Economic vulnerability, in which many people lose their livelihoods during a disaster

2. Vulnerability in the field of technology, i.e differences in access to technology between community groups. Between rich and poor groups, groups

3. Setbacks or underdevelopment, i.e vulnerability to the possibility of the community having to rebuild their lives, thereby needing assistance.

4. Vulnerability due to lack of or no experience of danger signs

5. Vulnerability due to rejecting norms, rules and regulations that are considered safe. In the end, the overall condition of vulnerability arises in the event of a disaster that is often present and is considered as not important that creates conditions

Five vulnerabilities that will be faced by the community, implementing mitigation and adaptation of volcanic earthquake disaster, is expected to not stop at certain targets but must always be maintained continuity. Under normal conditions, people may experience boredom when they have to follow the high frequency of meetings, counselling, and simulations that are held in their environment. This condition can certainly have an impact on the decreasing quality of preparedness. Although the saturation of this community has not been seen, this needs to be used as consideration for increasing public awareness by considering the allocation of time and energy from the community as well. This means that most people who live on the slopes of the mountain do not have regular income as formal employees so that the time and energy that should be productive for themselves and their families are taken up to participate in various programs that enter the region.

\section{CONCLUSION}

Dempo Volcano is one of the active volcanoes that have shown its activity and have a great chance at any time will occur volcanic earthquake, so that mitigation and adaptation measures that need to be done by the community around the Dempo Volcano area. In determining mitigation, physical, educational, and socio-economic use is used as a criterion with 8 alternative policies. Of the alternative policies, selected policies that become priorities to be applied in mitigating volcanic earthquakes in the following order: Participatory mapping to determine the hazards and risks of disasters, Increasing public awareness of volcanic earthquake disasters and their mitigation, Increasing coordination of related agencies, reviving wisdom local, building communication networks in the community, developing sister village programs, managing and structuring disaster-prone areas to reduce the threat of disasters, and programs to improve community preparedness in disaster management. Furthermore, adaptation has 3 criteria, physical, social, cultural and economic. Alternative as well as a priority in the implementation of successive volcanic earthquake adaptation, i.e: Changes in house construction to be earthquake resistant as a form of adaptation to earthquake disasters, Making youth as a driving factor in disaster risk reduction and increasing regional resilience. Application of local wisdom in daily life days, Building a culture of safety and resilience by using knowledge of innovation and education, Evacuation routes are accompanied by signs and preparing basic needs, doing alternative work to meet financial needs, Locating new homes closer to the main road, and separation of protected areas and clear cultivation areas. The 3 priorities in mitigating and adapting the volcanic earthquake-prone areas can be realized by implementing their achievement strategies. Thus, the community around Dempo Volcano, which could become victims of the volcanic earthquake, can be suppressed.

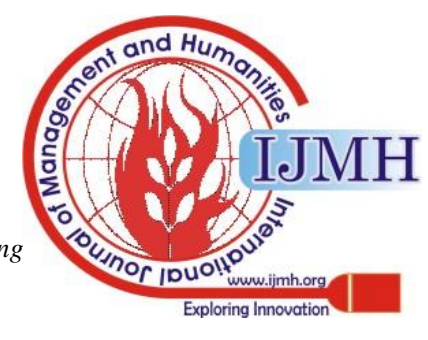




\section{ACKNOWLEDGEMENT}

This research was supported by Universitas Negeri Padang (UNP) and Pagar Alam City Government. We also thank of Chairman of Postgraduate UNP and Students involved in research for their support in this research.

\section{REFERENCES}

1. D. Hermon, Climate Change Mitigation. Rajawali Pers (Radjagrafindo) Jakarta, 2017

2. Badan Nasional Penanggulangan Bencana (BNPB), Peraturan Kepala Badan Nasional Penanggulangan Bencana Nomor 17 Tahun 2011, Pedoman Relawan Penanggulangan Bencana, 2011

3. D. Hermon, Ganefri, Erianjoni, I. Dewata, P. Iskarni, A. Syam, A Policy Model Of Adaptation Mitigation And Social Risks The Volcano Eruption Disaster Of Sinabung In Karo Regency-Indonesia, International Journal of GEOMATE, Vol.17, Issue. 60, pp.190-196, 2018

4. Kementerian Energi dan Sumber Daya Mineral Badan Geologi, Peningkatan Tingkat Aktivitas G. Dempo, 201

5. T.L. Saaty, Pengambilan Keputusan Bagi Para Pemimpin: Proses Hirarki Analitik untuk Pengambilan Keputusan dalam Situasi yang Kompleks, Pustaka Binaman Pressindo, 1993

6. Marimin, Teknik dan Aplikasi Pengambilan Keputusan Kriteria Majemuk, Grasindo: Jakarta, 2005

7. S. Latifah, Prinsip-prinsip Dasar Analytical Hierarchy Process, Jurusan Kehutanan, Fakultas Pertanian USU: Medan, 2005

8. K. Smith, Environmental Hazards: Assesing Risk and Reducing Disaster, Routledge: London, 1992

9. D. Hermon, Evaluation of Physical Development of the Coastal Tourism Regions on Tsunami Potentially Zones in Pariaman City-Indonesia. International Journal of GEOMATE, Vol.17, Issue.59, pp. 189-196. 2019

10. L. Arlym, D. Hermon, D. Lanin, O. Oktorie and A. Putra. A Policy Model of Preparedness The General Hospital in Reducing Victims of Earthquake and Tsunami Disasters in Siberut Mentawai Island, Indonesia. International Journal of Recent Technology and Engineering (IJRTE). Vol. 8. Issue 3. 2019

11. Hermon D. Mitigation and Adaptation DISASTER OF CLIMATE CHANGE. Sara Books Publication. 2019. Gujarat, India. 2019Sudibyakto, Persepsi Penduduk Merapi dalam Manajemen Bencana Indonesia Kemana?, Gadjah Mada University Press: Yogyakarta, 2011b

12. K. Kusumadinata, Data Dasar Gunung Api Indonesia: Catalogue of Refetence on Indonesia Vulcanoes with Eruption in Historical Time, Direktorat Jendral Pertambangan Umum dan Energi: Jakarta, 1979

13. D. Hidayati, Kajian Kesiapsiagaan Masyarakat Dalam Mengantisipasi Bencana Gempa Bumi dan Tsunami, LIPI-UNESCO/ISDR, 2006

14. E.K Maloney and D.P Coppola, Communicating Emergency Preparedness: Strategic For Creating a Disaster Resilient. Auerbach Publicationa Taylor \& Francis Group: USA, 2009

15. Sunarto, Kecerdasan Tradisional untuk Kajian Kebencanaan dalam Perspektif Hermeneutika, Jurnal Kebencanaan Indonesia, vol. 1, no. 5, 2008, pp. 323-334

16. F. Lavigne, B.J Coster, N. Juvin, F. Flohic, J.C Gaillard, P. Teixer, J. Morin, and J. Sartohadi, People's Behaviour in the Face of Volcanic Hazards: Perspectives from Javanese Communities, Indonesia, Journal of Volcanology and geothermal Research, vol. 172, pp. 273-287, 2008

17. K. Donovan, Doing Social Volcanology: Exploring Volcanic Culture in Indonesia, Area, Vol. 42, Issue. 1, pp. 117-126, 2010

18. J.B Bing, Mixing Knowledge to Negoti- ate With and on a Volcano", Journal of Al-pine Research, Vol. 102, Issue. 4, pp. 1-9 , 2014

19. A.K Jha, Safer Homes, Stronger Communities: A Handbook for Reconstructing after Natural Disaster. The World Bank: Washington: 2010

20. K.P. Sari, Priyo, A. Oktradiksa and A. Setiawan, Sistem Informasi Desa Dalam Mitigasi Bencana (Peran Desa Penyangga Dalam Implementasi Sister Village, Jurnal Mediteg, Vol. 3, Issue. 1, pp. 1-8, 2018

21. E. Barlian, D. Hermon and I. Umar, Kajian Dinamika Penduduk dan Dampaknya Terhadap Lingkungan di Kota Padang, 2011

22. D. Hermon, The Strategic Model of Tsunami Based in Coastal Ecotourism Development at Mandeh Regions, West Sumatera, Indonesia", Journal of Environment and Earth Science, Vol. 6, Issue. 4 pp. 40-45, 2016

23. I. Umar, I. Dewata, Mitigation Policy Directions In Flood Hazard Zone At Limapuluh Kota District, West Sumatra Province, Jurnal Pengelolaan Sumberdaya Alam dan Lingkungan, Vol. 8, Issue. 2, pp.251-257, 2018
Published By:

Blue Eyes Intelligence Engineering \& Sciences Publication

(c) Copyright: All rights reserved.

24. R. Sylves, Disaster Policy and Politics, Emergency management and Homeland Security, CQ Press: Washington DC, 2008

25. Wijanarko, Himawan, Disaster Management di Negeri Rawan Bencana, The Jakarta Consulting Grup: Jakarta, 2006

26. A. Özerdem and T. Jacoby, Disaster Management and Civil Society: Earthquake Relief in Japan, Turkey and India, I.B.Tauris \& Co Ltd: London, 2006

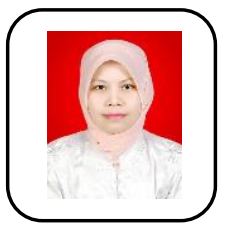

Aulia Asman is a Research, Nurse and Lecturer of Diploma III Nursing, Universitas Negeri Padang, obtained the Master Degree in Biomedical at Universitas Andalas. He is actively involved in any researches regarded to environmental health and produces several scientific works in the form of SINTA-Indonesia indexed journals (ID: 6698822). Right now he is a student Doctoral Program of Environmental Science, Universitas Negeri Padang and is also a member of the Indonesian National Nurses Association DPD Padang Pariaman.

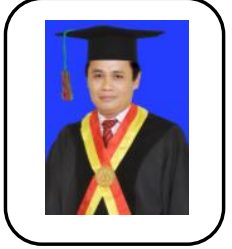

Dedi Hermon is a Professor of Disaster Geography, obtained the Doctorate Degree in Doctor Program Natural Resources Management and Environment at Bogor Agriculture University, 2009 He is actively involved in any researches regarded to natural disaster, land cover, carbon stock and produces several scientific works in the form of Scopus indexed journals (ID: 57200409691) and scientific books both national and international publications. He is assistant director of Postgraduate Universitas Negeri Padang as well as the head of Study Center of Disaster and Environment, Universitas Negeri Padang.

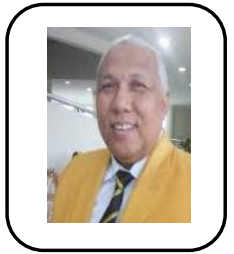

Eri Barlian is a Professor of Environmental Education, obtained the Doctorate Degree in Doctor Program Education Science at Universitas Negeri Jakarta, 1999. He is actively involved in any researches regarded to environmental education, sports, recreation and disaster and produces several scientific works in the form of Scopus indexed journals (ID: 57202293479). He is Chair of Doctoral Program of Environmental Science, Universitas Negeri Padang.

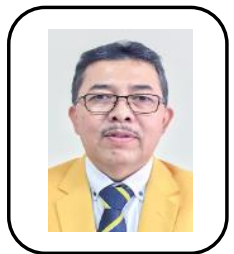

Indang Dewata is an Associate professor of Environmental Science, obtained the Doctorate Degree in Doctor Program Education Science at Universitas Indonesia, 2009. He is actively involved in any researches regarded to environmental science, chemical and produces several scientific works in the form of Scopus indexed journals (ID: 57202287960) He is Chair of Masters Program of Environmental Science, Universitas Negeri Padang.

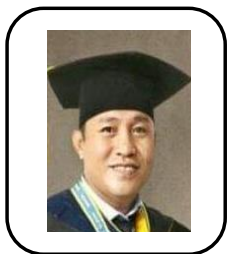

Iswandi Umar is an Associate professor of Environmental Science, obtained the Doctorate Degree in Doctor Program Natural Resources Management and Environment at Bogor Agriculture University, 2015. He is actively involved in any researches regarded to environmental science, geography and produces several scientific works in the form of Scopus indexed journals (ID: 57204825796). He is Chair of Masters Program of Geography Education, Universitas Negeri Padang.

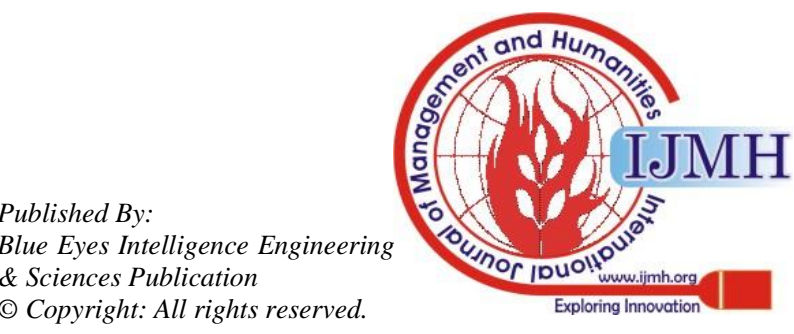

